Keywords: HB-Line, AFS-2, Purification, Oxalate Precipitation, Anion Exchange ,Calcination, Specification, MOX, Chloride, Fluoride

Retention: Permanent

\title{
Decontamination of Plutonium from Fluoride and Chloride during Oxalate Precipitation, Filtration and Calcination Processes
}

\author{
E. A. Kyser
}

July 2012

Savannah River National Laboratory Savannah River Nuclear Solutions Aiken, SC 29808 


\section{DISCLAIMER}

This work was prepared under an agreement with and funded by the U.S. Government. Neither the U.S. Government or its employees, nor any of its contractors, subcontractors or their employees, makes any express or implied:

1. warranty or assumes any legal liability for the accuracy, completeness, or for the use or results of such use of any information, product, or process disclosed; or

2. representation that such use or results of such use would not infringe privately owned rights; or

3. endorsement or recommendation of any specifically identified commercial product, process, or service.

Any views and opinions of authors expressed in this work do not necessarily state or reflect those of the United States Government, or its contractors, or subcontractors.

\section{Printed in the United States of America}

Prepared for U.S. Department of Energy 


\section{AUTHORS:}

original approved by E. A. Kyser

$7 / 25 / 2012$

E. A. Kyser

Date

Separations and Actinide Science Programs

TECHNICAL REVIEW:

original approved by W. D. King

$7 / 25 / 2012$

W. D. King Date

Advanced Characterization and Process

APPROVAL:

original approved by Samuel D. Fink

$7 / 27 / 2012$

S. D. Fink, Manager

Date

Separations and Actinide Science Programs

original approved by Bill Giddings for S. L. Marra

$7 / 30 / 2012$

S. L. Marra, Manager

Date

Environmental \& Chemical Process Technology Research Programs

original approved by K.P. Burrows

$7 / 31 / 2012$

K. P. Burrows, Manager

Date

HB-Line Engineering 


\section{Table of Contents}

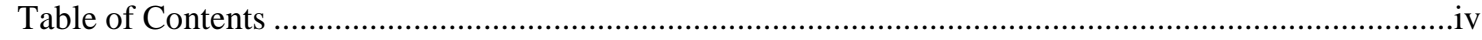

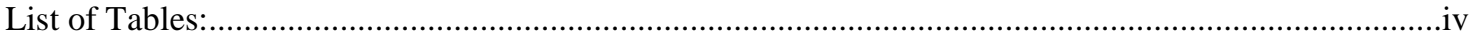

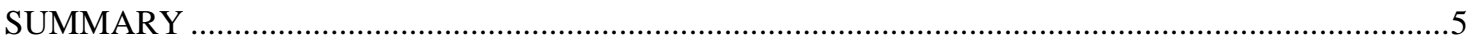

BACKGROUND

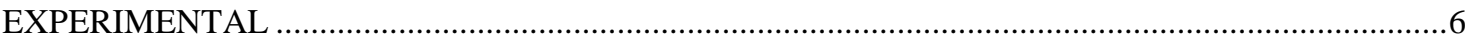

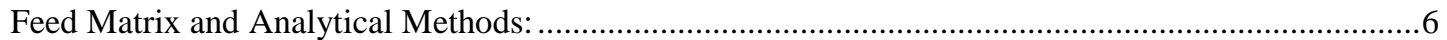

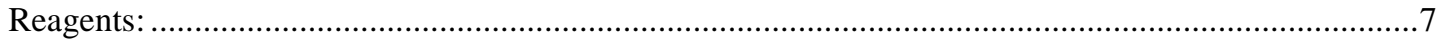

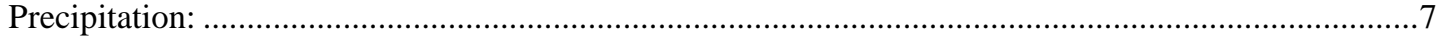

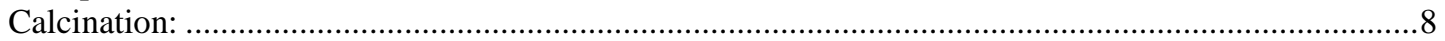

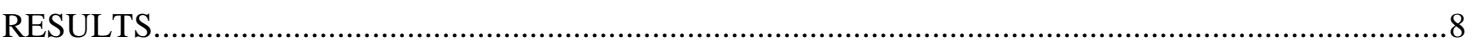

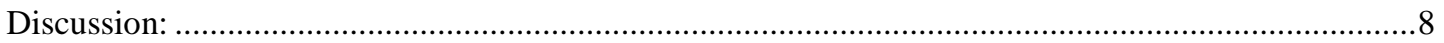

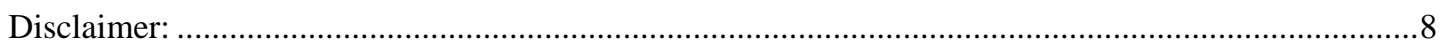

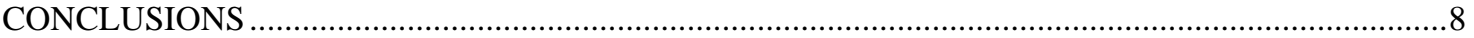

\section{List of Tables:}

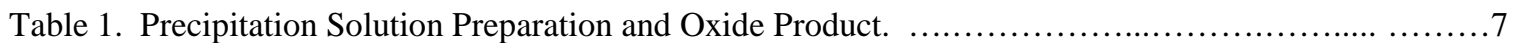

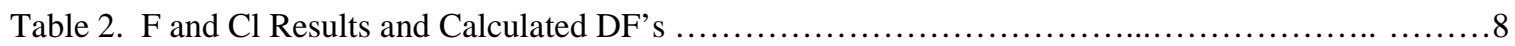




\section{Decontamination of Plutonium from Fluoride and Chloride during Oxalate Precipitation, Filtration and Calcination Processes}

\section{SUMMARY}

Due to analytical limitations for the determination of fluoride (F) and chloride (Cl) in a previous anion exchange study, an additional study of the decontamination of Pu from $\mathrm{F}$ and $\mathrm{Cl}$ by oxalate precipitation, filtration and calcination was performed.

Anion product solution from the previous impurity study was precipitated as an oxalate, filtered, and calcined to produce an oxide for analysis by pyrohydrolysis for total $\mathrm{Cl}$ and $\mathrm{F}$. Analysis of samples from this experiment achieved the purity specification for $\mathrm{Cl}$ and $\mathrm{F}$ for the proposed AFS-2 process. Decontamination factors (DF's) for the overall process (including anion exchange) achieved a DF of $\sim 5000$ for $\mathrm{F}$ and a DF of $\sim 100$ for $\mathrm{Cl}$. Similar experiments where both $\mathrm{HF}$ and $\mathrm{HCl}$ were spiked into the anion product solution to a $\sim 5000 \mu \mathrm{g} / \mathrm{g}$ Pu concentration showed a DF of 5 for F and a DF of 35 for $\mathrm{Cl}$ across the combined precipitation-filtration-calcination process steps. 


\section{BACKGROUND}

HB-Line Engineering requested that SRNL develop a flowsheet ${ }^{1}$ for the purification of Pu dissolved in H-Canyon to meet the Interface Control Document (ICD) limits ${ }^{2}$ for the Mixed Oxide MOX Fuel Fabrication Facility (MFFF). The flowsheet strategy is to measure most of the impurities present in the product solution from anion exchange to show compliance with the product specification. Anion exchange is used as the primary purification unit operation for this process but the downstream processes of oxalate precipitation, filtration and calcination provide some purification for several elements.

Fluoride (F) and chloride (Cl) are two anionic species that cannot be readily analyzed in nitric acid process solutions with sufficiently low detection limits to determine compliance with the specification. The prior impurity study ${ }^{3}$ observed detection limits for $\mathrm{F}$ in the plutonium hearts (i.e. anion exchange eluate) samples ranging from $<2000$ to $<10,000 \mu \mathrm{g} / \mathrm{g} \mathrm{Pu}$. The concentration of $\mathrm{Cl}$ in the anion feed is expected to always be low but was assumed to be bounded by a $5000 \mu \mathrm{g} / \mathrm{g}$ Pu concentration. The concentration of fluoride used in the upstream dissolution process is nominally $0.1 \mathrm{M}$ (or $\sim 400,000 \mu \mathrm{g} / \mathrm{g} \mathrm{Pu})$. The specification ${ }^{2}$ requires a total $\mathrm{Cl}+\mathrm{F}$ impurity concentration of less than $250 \mu \mathrm{g}(\mathrm{Cl}+\mathrm{F}) / \mathrm{g} \mathrm{Pu}$ for the $\mathrm{PuO}_{2}$ product. For a $\sim 50 \mathrm{~g} \mathrm{Pu} / \mathrm{L}$ solution this converts to $12.5 \mathrm{mg}$ $(\mathrm{Cl}+\mathrm{F}) / \mathrm{L}$ solution. These anions $(\mathrm{F}, \mathrm{Cl})$ may have some affinity for the resin. Even though the IC anions analytical method was not as sensitive as the other analytical techniques that we are using, the data obtained in the impurity study did show that $\mathrm{F}$ was removed to below the detection limit within 2 to 3 BV's of wash.

To confirm the capability of the process to produce material that meets the $(\mathrm{Cl}+\mathrm{F})$ specification $^{2}$, additional work was undertaken to investigate the behavior of $\mathrm{F}$ and $\mathrm{Cl}$ in oxalate precipitation and calcination to measure the additional DF provided by those process steps. This measurement was deemed especially important for F since it is added in a significant concentration in the H-Canyon dissolution process. To mitigate the limited analytical capability in solution for $\mathrm{F}$ and $\mathrm{Cl}$, a precipitation study was performed using Pu anion product solution from the impurity study where the neutron poisons (Gd or B) had been separated from the product by washing of the Pu-loaded column. The Pu product solution was oxalate-precipitated in a pair of tests with and without $\mathrm{HF}$ and $\mathrm{HCl}$ added (using the standard addition method). The product from each precipitation was filtered, (without a cake wash) and then calcined to $\sim 600+{ }^{\circ} \mathrm{C}$. It is believed that each of these steps will remove some $\mathrm{F}$ or $\mathrm{Cl}$ impurity. Both $\mathrm{HF}$ and $\mathrm{HCl}$ (simultaneously) were tested to determine the DF for these anions in the precipitation-calcination test. F Area laboratories performs a pyrohydrolysis analysis for $\mathrm{F}$ and $\mathrm{Cl}$ with a $\sim 20 \mu \mathrm{g} / \mathrm{g}$ Pu detection limit which is more than sufficient to determine $(\mathrm{F}+\mathrm{Cl})<250 \mu \mathrm{g} / \mathrm{g} \mathrm{Pu}$.

\section{EXPERIMENTAL}

Feed Matrix and Analytical Methods: The anion product solution from the previous column experiment $(\mathrm{Cr} 314)^{3}$ was used for this testing. Fluoride was measured in the original anion feed solution by IC anion but was below the method detection limit in the anion product. The $\mathrm{Cl}$ concentration was below the method detection limits in both the anion feed and product solutions. With the uncertainty in the results from the IC anions analytical method, the best value for the F anion exchange feed solution concentration was calculated from the mass measurement of the added reagent KF. A small amount of $\mathrm{Cl}$ was presumed present in the anion feed solution from an aliquot of ${ }^{137} \mathrm{Cs}$ that was used, but this amount was only known by calculation based on the stated concentration of $0.1 \mathrm{M} \mathrm{HCl}$ in the

\footnotetext{
1 J. W. Christopher, “Flowsheet Development for HB-Line Phase II Oxide Production,” NMMD-HTS-20113177, Revision 0 (Nov 10, 2011).

${ }^{2}$ Mixed Oxide Fuel Fabrication Facility (MFFF) - H-Area/K-Area Plutonium Dioxide Powder Interface Control Document, ICD-11-032-01, G-ESR-H-00189, Rev. 0, 05/31/2012

${ }^{3}$ E. A. Kyser, W. D. King, "HB-Line Anion Exchange Purification of AFS-2 Plutonium for MOX”, SRNL-STI2012-00233, Rev. 0, Savannah River National Laboratory, Aiken SC, April 2012.
} 
Table 1. Precipitation Solution Preparation and Oxide Product.

\begin{tabular}{|c|c|c|c|c|c|c|c|c|c|c|c|}
\hline $\begin{array}{c}\text { Mass } \\
\mathrm{g}\end{array}$ & Description & $\begin{array}{l}\text { Vol } \\
\mathrm{ml}\end{array}$ & $\begin{array}{l}\mathrm{Pu} \\
\mathrm{g} / \mathrm{L}\end{array}$ & $\begin{array}{c}\mathrm{Pu} \\
\mathrm{g}\end{array}$ & $\begin{array}{c}{[\mathrm{H}+]} \\
\mathrm{M}\end{array}$ & $\begin{array}{l}\mathrm{Cl} \\
\mathrm{M}\end{array}$ & $g / L$ & ug/gPu & $\begin{array}{l}\mathrm{F} \\
\mathrm{M}\end{array}$ & $g / L$ & ug/gPu \\
\hline \multirow{5}{*}{ g } & Cr314 Feed (Anion Feed Solut & & 4.43 & & & 0.0007 & 0.024 & 5415 & 0.098 & 1.86 & 419705 \\
\hline & Cr314PC1 & 15 & 53.3 & 0.80 & 1 & & & na & & & na \\
\hline & 0.9 M Oxalic Acid & 11 & & & 0.9 & & & & & & \\
\hline & DI H2O & 0.2 & & & & & & & & & \\
\hline & PulV Oxalate vial \#13 & 26.2 & 30.54 & 0.800 & 0.57 & & & & & & \\
\hline 1.441 & Wet Oxalate cake & & & & & & & & & & \\
\hline \multirow[t]{7}{*}{0.7185} & Calcined Oxide & & & & & & & & & & \\
\hline & Pu Oxide Vial HBL-623 & & & 0.63 & & & & 60 & & & 73 \\
\hline & Cr314PC1 & 15 & 53.3 & 0.80 & 1 & & & na & & na & \\
\hline & 0.9 M Oxalic Acid & 11 & & & 0.9 & & & & & & \\
\hline & $1.3 \mathrm{M} \mathrm{HCl}$ & 0.1 & & & 1.32 & & & & & & \\
\hline & $2.8 \mathrm{M} \mathrm{HF}$ & 0.1 & & & 2.37 & & & & & & \\
\hline & PulV Oxalate w Cl/F vial \#14 & 26.2 & 30.54 & 0.800 & 0.57 & 0.005 & 0.18 & 5,847 & 0.009 & 0.17 & 5,632 \\
\hline 2.634 & Wet Oxalate cake & & & & & & & & & & \\
\hline \multirow{2}{*}{0.9059} & Calcined Oxide & & & & & & & & & & \\
\hline & Pu Oxide Vial HBL-630 & & & 0.80 & & & & 146 & & & 996 \\
\hline
\end{tabular}

spike solution. By calculation, the $\mathrm{Cl}$ in the anion feed solution was $0.0007 \mathrm{M}$ or $\sim 5400 \mu \mathrm{g} / \mathrm{g} \mathrm{Pu}$ ( 20 $\mathrm{mg} \mathrm{Cl} / \mathrm{L})$.

Reagents: Reagent grade chemicals were used. Pu anion solution product (Cr314PC1) from experiment Cr314 was used as the feed solution for precipitation.

Precipitation: Chemical composition of the precipitation solution is shown in Table 1. The precipitations were performed in flat bottom test tubes in a water bath that was heated with an externalsensor-equipped hotplate. These test tubes were fabricated from quartz. The solutions were mixed with a magnetic stirrer and the water bath was heated to nominally $50{ }^{\circ} \mathrm{C}$. After precipitation, the oxalate slurry was filtered using ash-less filter paper, a standard filter funnel and an Erlenmeyer flask. New glassware was used to avoid cross contamination from past work. The initial filtrate solution was re-used to rinse the precipitate from the test tube into the funnel. No clean cake wash was used. After filtration, the wet cake was transferred to a small quartz crucible and sealed for transfer to another glovebox for calcination. The non-spiked sample was prepared and filtered first to limit the opportunity for cross-contamination. Later, the Cl- F-spiked sample was prepared, filtered and sealed for transfer in the same manner as the first sample. The main difference between the two samples (other than the addition of spike solutions) was that the non-spiked precipitate was not air-dried for as long of a time and was noticeably wetter, making complete transfer more difficult. The spiked sample was allowed to dry overnight and was easily removed from the filter paper with very little residue left on the filter paper. Both samples were weighed but due to the high water content and the differences in drying, this information has limited meaning. 
Table 2. F and Cl Results and Calculated DF's.

\begin{tabular}{cclcccccc}
\hline FHL & & SRNL Sample & F & Ave & \multicolumn{2}{c}{ Cl } & Ave \\
LIMS ID \# & Description ID \# & & ug/g of sample & \multicolumn{3}{c}{ ug/g of sample } \\
\hline 200598864 & HBL-630 & Cl/F Spiked & 983 & 1008 & 996 & 145 & 146 & 146 \\
& & DF Observed & 5 & & & 35 & & \\
200598865 & HBL-623 & Unspiked Sample & 71 & 59 & 65 & 50 & 57 & 54 \\
& & DF IX-oxide & 5634 & & & 100 & & \\
\hline
\end{tabular}

Calcination: After transfer to another glovebox, both samples were calcined to greater than $600{ }^{\circ} \mathrm{C}$ (oven temperature) for at least two hours. The conditions were deliberately less extreme than actual process conditions to provide a bounding DF measurement. A ceramic crucible holder made from firebrick was used to keep the small crucibles upright during calcination. After calcination was complete, these samples were weighed again as oxide and the amount of Pu present was calculated assuming the theoretical $88.1 \mathrm{wt} \%$ assay for pure Pu oxide. Later the oxide samples were transferred to a $\mathrm{B}$-Vial for shipment to F/H Laboratories for pyrohydrolysis analysis. This method used high temperature and steam to transfer volatile species, such as $\mathrm{HCl}$ and $\mathrm{HF}$, from the oxide to a condensed water phase which was then analyzed without the acid interferences seen in process solutions.

\section{RESULTS}

Each sample was analyzed in duplicate. As part of the analytical method, blank corrections were determined. The F blank corrections were zero in both duplicates for each sample. The blank corrections for $\mathrm{Cl}$ amounted to $4 \%$ to $6 \%$ of the $\mathrm{Cl}$ values measured for the two samples analyzed. The analytical results are reported in Table 2. On average, the non-spiked sample measured $65 \mu \mathrm{g} \mathrm{F} / \mathrm{g} \mathrm{Pu}$ oxide and $54 \mu \mathrm{g} \mathrm{Cl} / \mathrm{g}$ Pu oxide. When converted from oxide to a Pu basis these values will be about $12 \%$ higher (or $135 \mu \mathrm{g}(\mathrm{Cl}+\mathrm{F}) / \mathrm{g} \mathrm{Pu}$ ) which is well within the ICD specification. The final oxide product for the spiked sample was 15 times higher in $\mathrm{F}$ and 3 times higher in $\mathrm{Cl}$ than the non-spiked sample. Calculation of DF's across the combined precipitation-filtration-calcination process steps results in DF values of $\sim 5$ for $\mathrm{F}$ and $\sim 35$ for $\mathrm{Cl}$. Taking into account the $\mathrm{F}$ and $\mathrm{Cl}$ concentrations in the anion feed solution; an overall DF of $\sim 5600$ was measured for F but only $\sim 100$ for $\mathrm{Cl}$ for the nonspiked sample.

Discussion: It appears that there could be a Pu-F interaction that limits the DF for F in oxalate precipitation. On the other hand the overall $\mathrm{DF}$ for $\mathrm{Cl}$ was 50 times lower than that observed for $\mathrm{F}$. It seems likely that the relatively low concentrations of $\mathrm{Cl}$ in the anion feed solution is limiting the ability to measure the DF.

Disclaimer: This report involves determinations on only two samples and the reproducibility of these results can only be speculated. The actual determination by pyrohydrolysis appears to have reasonable sensitivity and reproducibility based on the blanks and the duplicate sample analyses.

\section{CONCLUSIONS}

Anion product solution from the previous impurity study was precipitated as an oxalate, filtered, and calcined to produce an oxide for analysis for total $\mathrm{Cl}$ and $\mathrm{F}$. These analyses show that the product oxide achieved the purity specification for $\mathrm{Cl}$ and $\mathrm{F}$ for the proposed process. A similar solution where both $\mathrm{HF}$ and $\mathrm{HCl}$ were spiked into the anion product solution showed a DF of 5 for $\mathrm{F}$ and a DF of 35 for $\mathrm{Cl}$ across the combined precipitation-filtration-calcination process steps. 


\section{Distribution:}

S. D. Fink, 773-A

K. M. Fox, 999-W

B. J. Giddings, 786-5A

C. C. Herman, 999-W

S. L. Marra, 773-A

F. M. Pennebaker, 773-42A

W. R. Wilmarth, 773-A

W. E. Harris, 704-2H

J. B. Schaade, 704-2H

G.J. Zachman, 225-7H

P. B. Andrews, 704-2H

S. J. Howell, 703-3H

M. J. Swain, 703-H

M. J. Lewczyk, 221-H

K. P. Burrows, 704-2H

J. E. Therrell, 704-2H

J. W. Christopher, 704-2H

J. E. Elkourie, 704-2H

A.T. Masterson, 704-2H

R. H. Smith, 704-2H

R. R. Livingston, 730-2B

J. L. O’Conner, 704-2H

W. G. Dyer, 704-2H

S. L. Hudlow, 221-H

E. A. Kyser, 773-A

T. S. Rudisill, 773-A

R. A. Pierce, 773-A

W. D. King, 773-42A

M. L Crowder, 773-A

J. M. Duffey, 773-A

M. C. Thompson, 773-A

W. L. Melton, 707-F

S. A. Thomas, 403-46A 